\title{
Stenogrammitis myosuroides (Polypodiaceae): a new addition to the European flora from southwest Ireland
}

\author{
Rory L. Hodd ${ }^{1} *$; Fred Rumsey ${ }^{2}$ \\ ${ }^{1}$ Nimbosa Ecology, Kerry, Ireland; ${ }^{2}$ Natural History Museum, London, England \\ *Corresponding author: Rory L. Hodd: rlhodd@gmail.com
}

This pdf constitutes the Version of Record published on $31^{\text {st }}$ August 2020

\begin{abstract}
The occurrence of the fern Stenogrammitis myosuroides (Sw.) Labiak in Europe is reported for the first time. A small population was discovered on two boulders beside a stream in Atlantic oak woodland in the Killarney National Park, Co. Kerry, in southwest Ireland. The main identification features of this taxa and features that distinguish it from other similar taxa are laid out and discussed. S. myosuroides is elsewhere known to occur in the Neotropics, in Cuba, Jamaica and the Dominican Republic, and is thought to have colonised its Irish site through long-distance spore dispersal. Two Grammitid species of similar ecology have been discovered in the Azores in the past five decades and a number of bryophyte species share a similar disjunct distribution between Ireland and the Neotropics, all of which supports the theory that long-distance dispersal is the most plausible explanation for the occurrence of $S$. myosuroides in Ireland. It is not clear how long $S$. myosuroides has been present in Ireland, although morphological differences suggest that it may have been separated from the Neotropical populations for a long period. However, molecular analysis is required to elucidate this.
\end{abstract}

Keywords: Fern; neotropical; long-distance dispersal; disjunct distribution.

\section{Introduction}

While exploring an area of old Atlantic oak (Quercus petraea (Matt.) Liebl.) woodland, within the Killarney National Park, Co. Kerry, during a meeting of the British Bryological Society (BBS) in July 2019 (Hodd, 2020), a small, unfamiliar fern was encountered by RLH growing on a boulder beside a stream. At first visual examination, it was mistaken for a species of moss in the genus Fissidens Hedw., but closer examination revealed it to consist of thickened opaque fronds, of very different structure to a moss, with sporangia present on the undersides of some fronds, and a network of rhizoids anchoring it to the rock surface. The species was unfamiliar to all members of the group, with a suggestion from those with experience of tropical botany that it may be a Grammitid fern. A single plant, with sporangia, was collected and sent to FJR at the Natural History Museum, London, who subsequently identified it as Stenogrammitis myosuroides, new to Europe.

\section{Habitat and ecology of Irish population}

S. myosuroides is known to grow on two large sandstone rocks, separated by a distance of $c .6 \mathrm{~m}$, along a small stream cascading down a bouldery slope within 
humid woodland, under a dense canopy of Quercus petraea, Fraxinus excelsior L. and Corylus avellana L. (Fig. 1). Immediate associates on the rocks on which $S$. myosuroides grows are mainly bryophytes, with the following species noted: Adelanthus decipiens (Hook.) Mitt., Aneura pinguis (L.) Dumort., Campylopus atrovirens De Not., Diplophyllum albicans (L.) Dumort., Hyocomium armoricum (Brid.) Wijk \& Margad., Marsupella emarginata (Ehrh.) Dumort. var. emarginata, Oxystegus daldinianus (De Not.) Köckinger, O. Werner \& Ros, Plagiochila exigua (Taylor) Taylor and Saccogyna viticulosa (L.) Dumort.

A

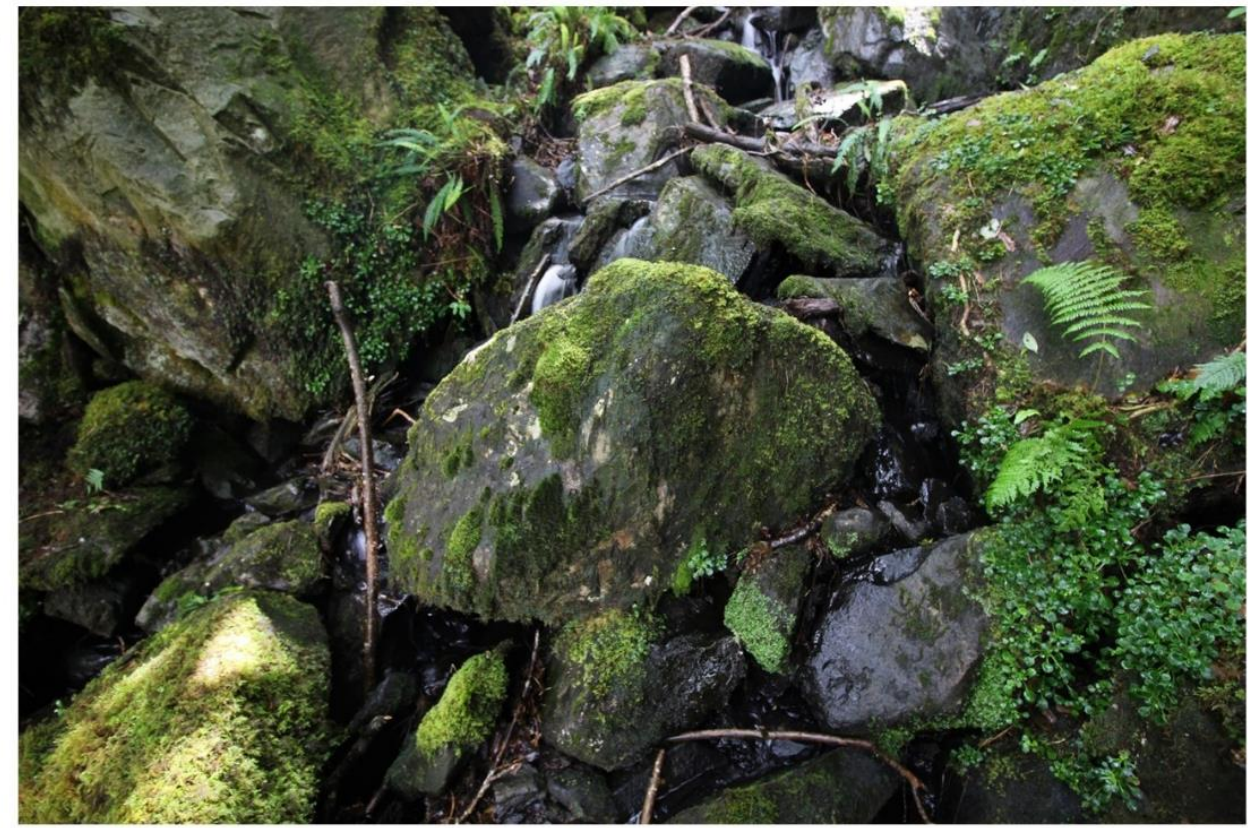

B

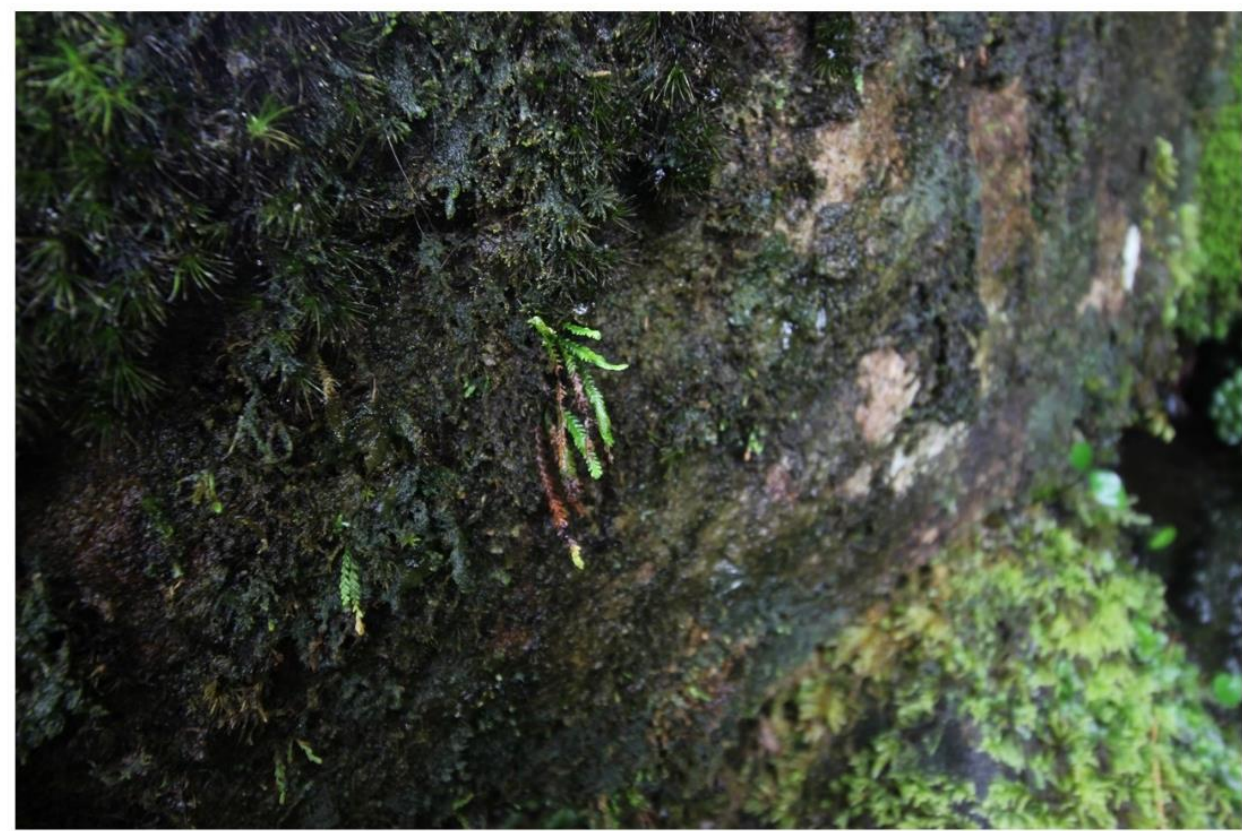

Figure 1. Distant (A) and closer (B) photographs of the habitat of Stenogrammitis myosuroides in the Killarney National Park. 
The only vascular plant associate recorded was the fern Hymenophyllum wilsonii Hook. The wider woodland is particularly rich in oceanic bryophyte species, with notable species present including Acrobolbus wilsonii Nees, Cyclodictyon laetevirens (Hook and Taylor) Mitt., Hageniella micans (Mitt.) B.C. Tan \& Y. Jia, Lejeunea flava (Sw.) Ness subsp. moorei (Lind.) R.M. Schust., Lejeunea hibernica Bischl. H.A. Mill. \& Bonner ex Grolle, Leptoscyphus cuneifolius (Hook.) Mitt., Plagiochila heterophylla Lindenb. var. heterophylla (syn. P. atlantica E.W. Jones \& F. Rose), Radula holtii Spruce and Sematophyllum demissum (Wilson) Mitt.

The larger population is found on the upper rock of the two on which $S$. myosuroides occurs, where plants are scattered across an area of $c .1 \mathrm{~m} \times 30 \mathrm{~cm}$, on the vertical face and underside of the rock, above the flow of the stream, facing northeast. A total of 40 plants are present, two of which were producing sporangia. Many of the plants are very small and some showed signs of browning, with the largest plants reaching $5 \mathrm{~cm}$ in length. On the lower boulder, a total of six plants occur across an area of $10 \mathrm{~cm} \times 20 \mathrm{~cm}$, one of which was producing sporangia at the time of the survey.

No immediate threats to these populations were noted, although the highly invasive shrub Rhododendron ponticum $\mathrm{L}$. is present within the surrounding woodland and may spread to the area in which $S$. myosuroides occurs, unless action is taken to control its spread. It is possible that the extra shade provided by $R$. ponticum may be beneficial to $S$. myosuroides, as has been observed for some bryophyte species with tropical affinities in Western Ireland (Hodd, 2015), but it would not be advisable to put this hypothesis to the test. These populations would also be vulnerable to random erosion events, if high volumes of water in the adjacent stream were to displace rocks or scour the surface of the boulders on which the populations grow.

\section{Description (from Irish material)}

Diminutive evergreen fern, epipetric; rhizome erect to short creeping, bearing redbrown, clathrate somewhat iridescent scales, to $c .1 .5 \mathrm{~mm}$, with a short apical cilium, medial cells elongated (two-three times longer than wide); petioles to $c .1 \mathrm{~cm} \times 0.3$ $\mathrm{mm}$ dark brown; lamina chartaceous to sub-coriaceous, $1.5-5.5 \times 0.2-0.4 \mathrm{~cm}$, erect or slightly arcuate, linear, hemi-dimorphic; sterile portion deeply pinnatisect, progressively reduced at the base, the basal segments more markedly asymmetrical and decurrent, the segments at the medial portion $1.5-2 \times 0.5-1.0 \mathrm{~mm}$, linear, set at $45-50^{\circ}$ to the rachis, somewhat asymmetrical at the base (the basiscopic side slightly decurrent), the apex obtuse, slightly pubescent on laminar tissue, veins and margins, the hairs reddish, rigid and straight, c.0.2-0.6 mm long, simple, 1-or ?2furcate, spreading; fertile portion crenulate, cut to $c .1 / 6$ the way to the rachis, equal to or shorter than the sterile portion; rachis with dark sclerenchyma exposed abaxially, covered by the laminar tissue adaxially, pubescent, the hairs similar to those from the petiole and lamina; sinuses +/- equal the segments width, to significantly < than width on sterile fronds; veins simple, not visible in the sterile portion, but with the dark sclerenchyma exposed in the fertile portion beneath the sporangia, adaxially with linear, well-marked hydathodes; sori naked, infra-medial, elliptic, conspicuously confluent at maturity; spores green, trilete, papillate $c .25 \mu \mathrm{m}$ in diameter. 
S. myosuroides is unlike any other European fern and because of its size and habit more likely to be mistaken for a bryophyte such as Fissidens. Similar species occur within the core area of its neotropical range and the characters by which it has been identified and can be distinguished are discussed below.

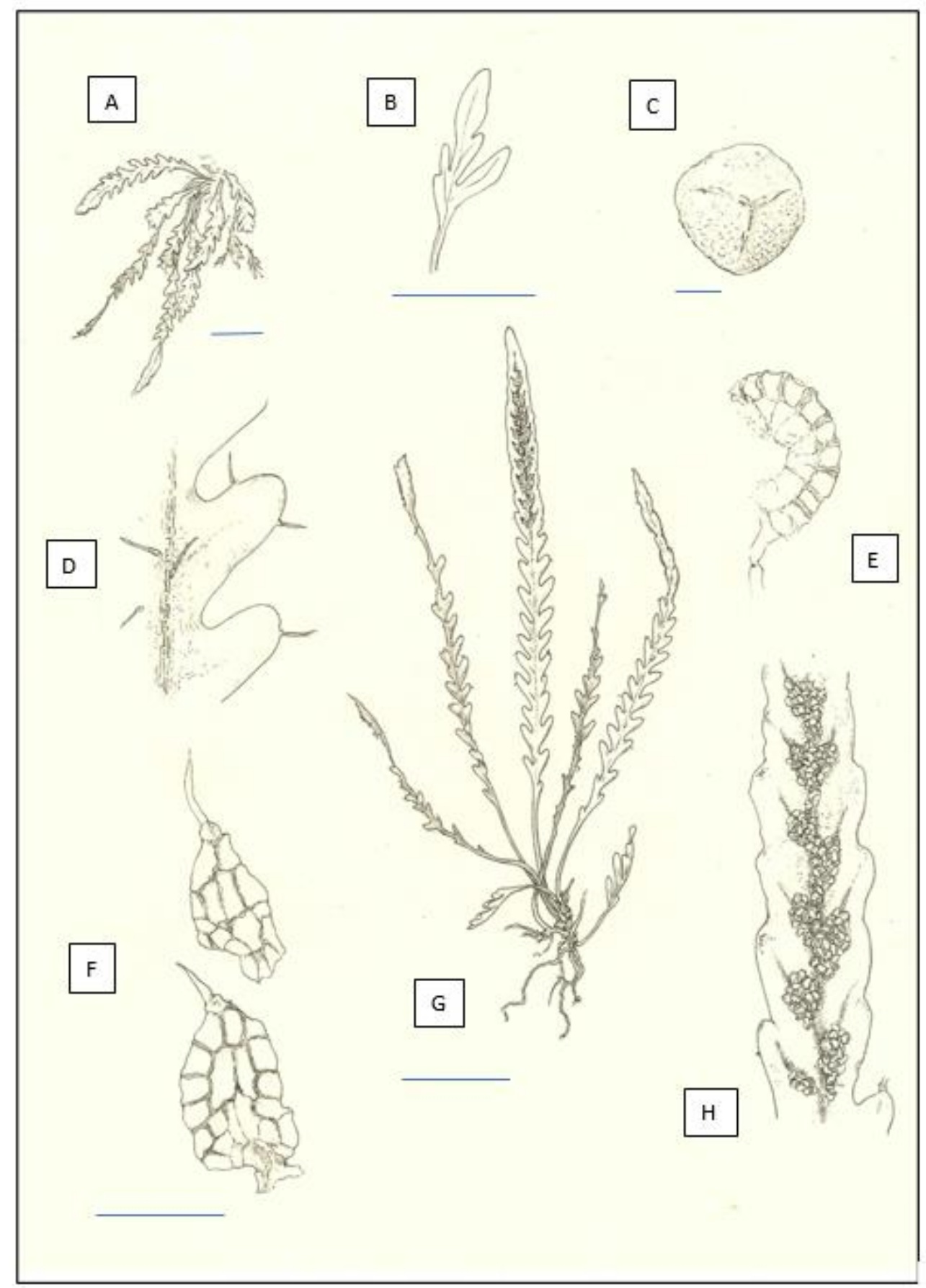

Figure 2. Stenogrammitis myosuroides from Co. Kerry.

A. Habit, B. Juvenile frond, C. Spore, D. Frond detail showing hairs, E. Dehisced sporangium, F. Clathrate rhizome scales, G. Whole plant, $H$. Detail of fertile portion of frond.

Scale bars: A, B \& G $=1 \mathrm{~cm}, C=10 \mu \mathrm{m}, F=1 \mathrm{~mm}$ 


\section{Identification}

The mystery Irish plant could rapidly be identified as a Grammitid based on its size, habit and soral features. Deciding which of the many hundreds of species of these small, epiphytic/epipetric predominantly tropical ferns, or indeed whether it was entirely novel, was more challenging. Resolution of the plant's identity would have a strong influence on its likely status. One plausible scenario was that the plant may have originated via spore dispersal from a garden source, potentially occurring there as an epiphyte on imported mature tree-fern trunks from Australasia (see Rumsey et al. (1993), Holyoak \& Lockhart (2009) and Pyner (2016) for other examples). Conversely, were the species to be a natural colonist, a neotropical origin would be more likely as this distribution pattern is demonstrated by a range of "Atlantic" cryptogamic taxa and the nearest native, Azorean, examples of this group of ferns. The relevant literature from Australasia and Central America and the Antilles was consulted and from the very distinctive morphology it was rapidly possible to rule out any taxon from the former floristic region, whereas several possibilities existed in the latter.

The taxonomy of the Grammitids has undergone dramatic revision over the last 30 years. Formerly accorded family status as the Grammitidaceae, molecular studies have clearly shown this group to be nested within the Polypodiaceae (Ranker et al., 2004; Schneider et al., 2004; Schuettpelz \& Pryer, 2007). Placed as an informal group without rank within the subfamily Polypodioideae by Christenhusz, Zhang \& Schneider (2011), the consensus classification (PPG1) presented by the Pteridophyte Phylogeny Group (Schuettpelz et al., 2016) elevated the Grammitids to sub-family level within the Polypodiaceae, as the Grammitidoideae Parris \& Sundue. Within this they recognised 33 genera. Of these, the type, Grammitis Sw. was formerly a large (several hundred species) and morphologically varied genus, which has seen many segregates created. These were largely defined initially by molecular phylogenetic studies for which supporting apomorphic morphological characters were later identified. It is still considered paraphyletic, with the monophyletic genus Cochlidium nested within it (Sundue et al., 2014). Superficially the Irish plant resembles the most common member of the sub-family in the New World, Cochlidium serrulatum (Sw.) L.E. Bishop (syn. Xiphopteris serrulata (Sw.) Kaulf.). This is distributed from the South of Mexico, through Mesoamerica, Colombia, Venezuela, Ecuador, Peru, Bolivia, Brazil, the Antilles, to the Old World in Mauritius, Madagascar and Tropical Africa and would thus be a likely candidate as a proven wide colonist. An epiphyte of forests at lower $(<1800 \mathrm{~m})$ altitudes, this species is, however, distinguished from the Irish plant by the lack of the darkened fertile veins and in being glabrous, i.e. lacking the small, often furcate reddish hairs shown by our plant. The admittedly similar hemi-dimorphic fronds tend to have somewhat more acute serrations but are easily mistaken. Indeed, Stenogrammitis jamesonii (Hook.) Labiak has twice been described as an infraspecific taxon of this species, as Polypodium serrulatum var. major Mett. and $P$. serrulatum forma minor Hieron. (Labiak, 2011). Cochlidium serrulatum is also of note as the only grammitid that has been claimed to have been successfully cultivated, which has implications for the Irish plant's status (see later discussion). When considering other plausible range disjunctions the only representative of the Grammitidoideae within N. America, Grammitis nimbata (Jenman) Proctor (syn. Xiphopteris nimbata (Jenman) Copel. although perhaps better placed within Cochlidium?) also shows similarities. It is only 
known from a single site in Macon Co., N. Carolina, (Farrar, 1967), where it persists predominantly as its gametophyte generation, a gemmiferous elongate-cordate thallus resembling a small thallose liverwort, although small sterile sporophytes are produced in favourable years (Smith, 1993). The nearest locations to its only American site are in Cuba, Hispaniola and Dominica, over 1,500 km distant, so it too shows impressive dispersal capabilities. The behaviour of this tropical disjunct when in a more temperate environment (the production of independent gametophytes reproducing in the absence of the sporophyte), is mirrored in the USA and Europe by examples of the Hymenophyllaceae (Farrar, 1967; Rumsey et al., 1993), The best known example is the Killarney fern (Vandenboschia speciosa (Willd.) Kunkel) (Rumsey et al., 1998), named for the area, now a National Park, where the Grammitid was discovered. We can, however, also rule out the American species as it differs in producing monomorphic fronds.

The Irish plant possesses a suite of characters (Fig. 2): having the veins unbranched and single in each segment, the fertile veins with visible dark sclerenchyma, one sorus per segment, linear hydathodes and the possession of hemi-dimorphic fronds, i.e. fertile fronds differing from the sterile in that the fertile portion is less dissected, which have been used to define the genus Stenogrammitis. These are all, however, characters which separately are shown by other Grammitis sensu lato, and superficially the Irish plant is difficult to distinguish from some species in other genera, particularly the afore mentioned Cochlidium serrulatum (Sw.) L.E. Bishop).

Stenogrammitis is one of the most recently described Grammitid genera (Labiak, 2011), segregated from the genus Lellingeria, itself only first circumscribed twenty years previously (Smith et al.,1991). Its name is derived from the Greek Steno, meaning narrow, as the fronds are typically only a few millimetres wide. Labiak (2011) recognised 24 species within his new genus; 12 in the neotropics, six in Africa, four in Madagascar and two on Pacific islands, a further neotropical species has subsequently been described (Labiak, 2012). Of these the majority exhibit hemidimorphism, the extent of dissection within the fertile portion is however rather varied between taxa and that, and the relative proportions of the fertile and sterile sections, provide useful diagnostic characters. From published illustrations and regrettably limited herbarium material we initially considered that the Irish plant might be conspecific with $S$. jamesonii (Hook.) Labiak from Central America, south to Brazil, and presented it as such at the BSBI Annual Exhibition Meeting in 2019. This plant has been hitherto greatly confused with Cochlidium serrulatum as already mentioned. Maxon (1905) believed it to be synonymous with the plant now known as $S$. myosuroides (Sw.) Labiak, the type of the genus Stenogrammitis, recorded from Cuba, Jamaica and the Dominican Republic. Labiak (2011) however recognised these as distinct but did not give distinguishing characteristics in what was primarily a nomenclaturally focused paper. Following correspondence he has very kindly made available to us his unpublished monograph on the genus and has commented on our plant's identity based on the illustrations which form Fig. 2. suggesting it more closely resembles $S$. myosuroides. 

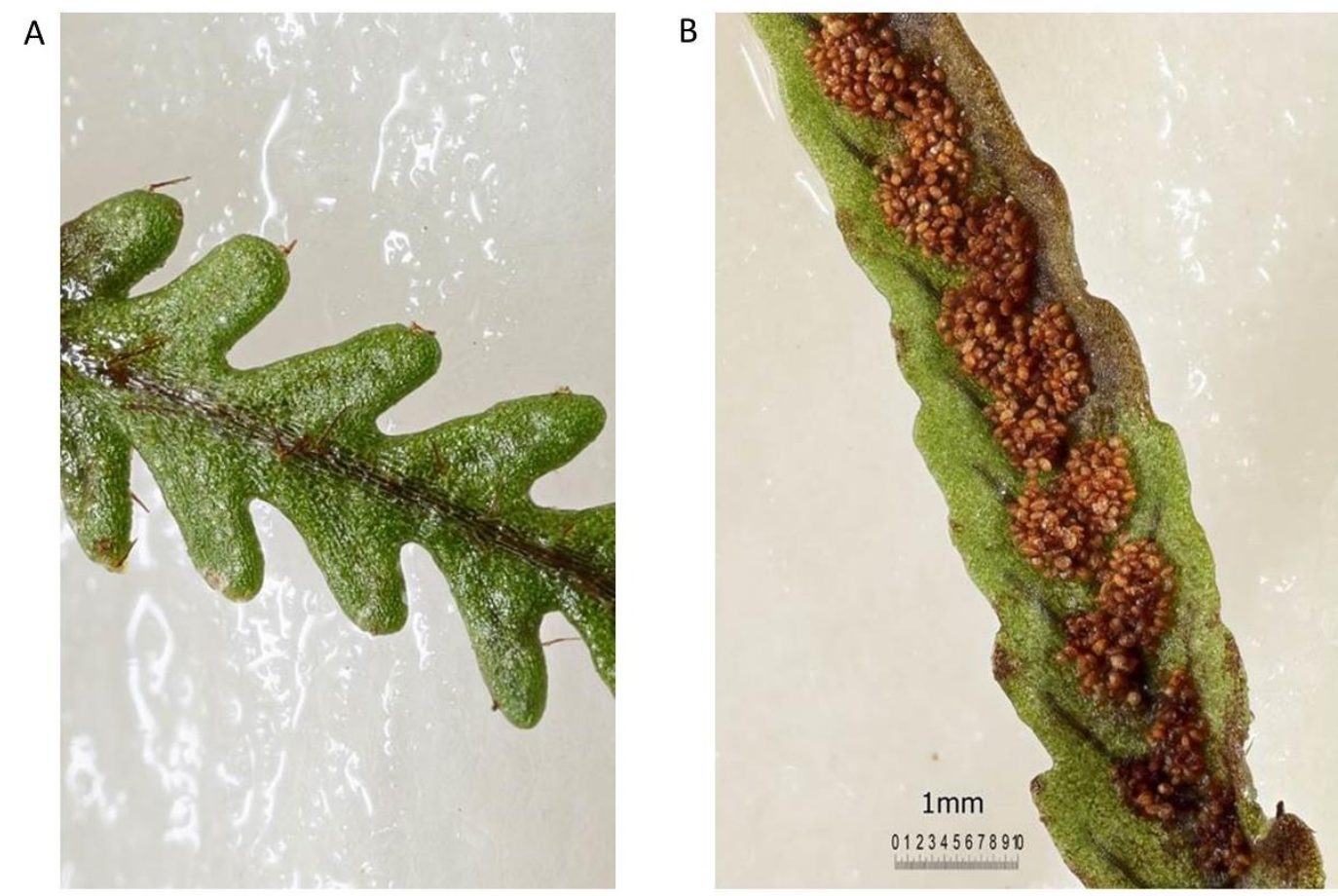

Figure 3. A. Detail of dorsal side of lower portion of frond of Stenogrammitis myosuroides. B. Ventral view of upper portion of fertile frond with sori present note the blackish sclereids.

The chief distinguishing characteristics between $S$. myosuroides and $S$. jamesonii can be summarised thus; the latter is larger, typically its fronds exceed $8 \mathrm{~cm}$ and are more coriaceous (cf. 3-6 cm and chartaceous), with medial segments set at 70-80 to the rachis $\left(c f .45-50^{\circ}\right)$, deltoid, $<2 \times$ longer than wide, ( $c f$. linear, $>3$ longer than wide), the fertile portion longer than the sterile portion ( $c$. equal than to shorter than sterile), the hairs on petiole and rachis never 2-furcate (some hairs 2-furcate). The Irish plant (Fig. 3 ) is clearly close to $S$. myosuroides, although smaller than typical, the fronds more coriaceous, the segments more closely spaced and 2-3x longer than wide, the sparse reddish hairs possibly longer (to $0.6 \mathrm{~mm}$ ), the rhizome scales more ovate and the plants are growing epipetrically, not epiphytically. To what extent these differences may result from climatic or edaphic responses are unclear. S. myosuroides is clearly variable in its neotropical range however, and in the absence of molecular comparisons and the study of more material it would seem hasty to recognise the Irish plant as taxonomically distinct at this point. That it would appear to show some subtle distinctions might argue for a lengthy period of isolation for this population rather than a recent colonisation.

\section{Considerations as to status - can it be native?}

Stenogrammitis species are not cultivated, indeed Grammitids more generally are renowned for their impossibility in cultivation. We can thus rule out dispersal from a cultivated source, or indeed deliberate introduction from a horticultural source. The species, as with other Grammitids, is always uncommon and highly localised within its native range - remote montane cloud-forest in Jamaica, Cuba and the Dominican Republic (Fig. 4) from which it is unlikely to have been deliberately or even unwittingly transported. Its Irish locality is itself remote, not on any footpath or track 
and over an hour's walk from the nearest vehicle access. Is it feasible that the species might have arrived naturally through long distance spore dispersal? Grammitids are known to be good colonists, well represented in the floras of isolated oceanic islands. The nearest extant Grammitids are Ceradenia jungermannioides (Klotzsch) L.E. Bishop and Grammitis azorica (H. Schäef.) H. Schäef., cloud-forest epiphytes of the Western and Central Azores, both of which are considered native. The former was detected first in 1973 (Rasbach et al., 1974) as a single individual on Pico Island, it was not reported again until 1991, when found in small quantity in four locations (Hansen, 1991). It was found again as a single plant on the island of Terceira in 1999, and as a total of $c .60$ individuals within six monads on the westernmost island of Flores in 2000 (Schäfer, 2001). It is currently listed as CR on the European Red-List (García Criado et al., 2017) based on population size and habitat vulnerability. Elsewhere it is distributed over a similar range to that of Stegnogrammitis jamesonii and $S$. myosuroides combined, Central America southwards to Brazil and in the Antilles. Morphologically the Azorean plants are indistinguishable from those of the Neotropics but no molecular comparison has yet been made. The second Azorean Grammitid, Grammitis azorica is also accorded CR status (García Criado et al., 2017) but is rarer still. It was first discovered as a single individual on Pico Island in 1991 (Hansen, 1992) but misidentified. It has not been re-found here. Schäfer (2001) reported it, under the name G. marginella (Sw.) Sw. subsp. azorica H. Schäef., as present on Flores, with 22 plants in seven monads. It was subsequently discovered as fewer than 10 individuals in two localities on Terceira (Elias, pers. comm.). Following further studies Schäfer (2005) raised the Azorean plant to specific level, although its morphological distinctions from the neotropical $G$. marginella are slight. What we believe to be germane to the discussion of the Irish Grammitid's status are the late discovery dates, similarly extremely small and clustered populations and the similarities in neotropical range of the species, or their nearest relatives. We might reasonably expect Stenogrammitis to also occur on the Azores, although possibly the precise epipetric habitat by streams in open woodland may not be present.

There exists within the British and Irish cryptogamic flora a small but very distinctive floristic assemblage with neotropical affinities, primarily made up of a range of hepatic species of hyper-oceanic conditions, eg. Leptoscyphus cuneifolius. While the majority of these are also located within Macaronesia, at least one species, Plagiochila heterophylla var. heterophylla is not, being exclusively neotropical and then disjunct to the Atlantic coasts of Britain and Ireland. It is perhaps telling that both of these rare species were found to be particularly abundant in the immediate vicinity of the Irish Stenogrammitis site.

As the spores of the Stenogrammitis are very small $(c .25 \mu \mathrm{m})$, comparable in size to that of a bryophyte (Hill et al., 2007), it's dispersal capabilities would be similar to bryophyte species that show a similar disjunct distribution. A further factor that would aid its long-distance dispersal is the high altitude of the montane forest in which it grows in its Neotropical range, enabling the release of spores into the air currents. The prevailing wind in Ireland is from the southwest (Sweeney, 2014), with the Jet Stream blowing across the Atlantic, often at high speeds, which would 


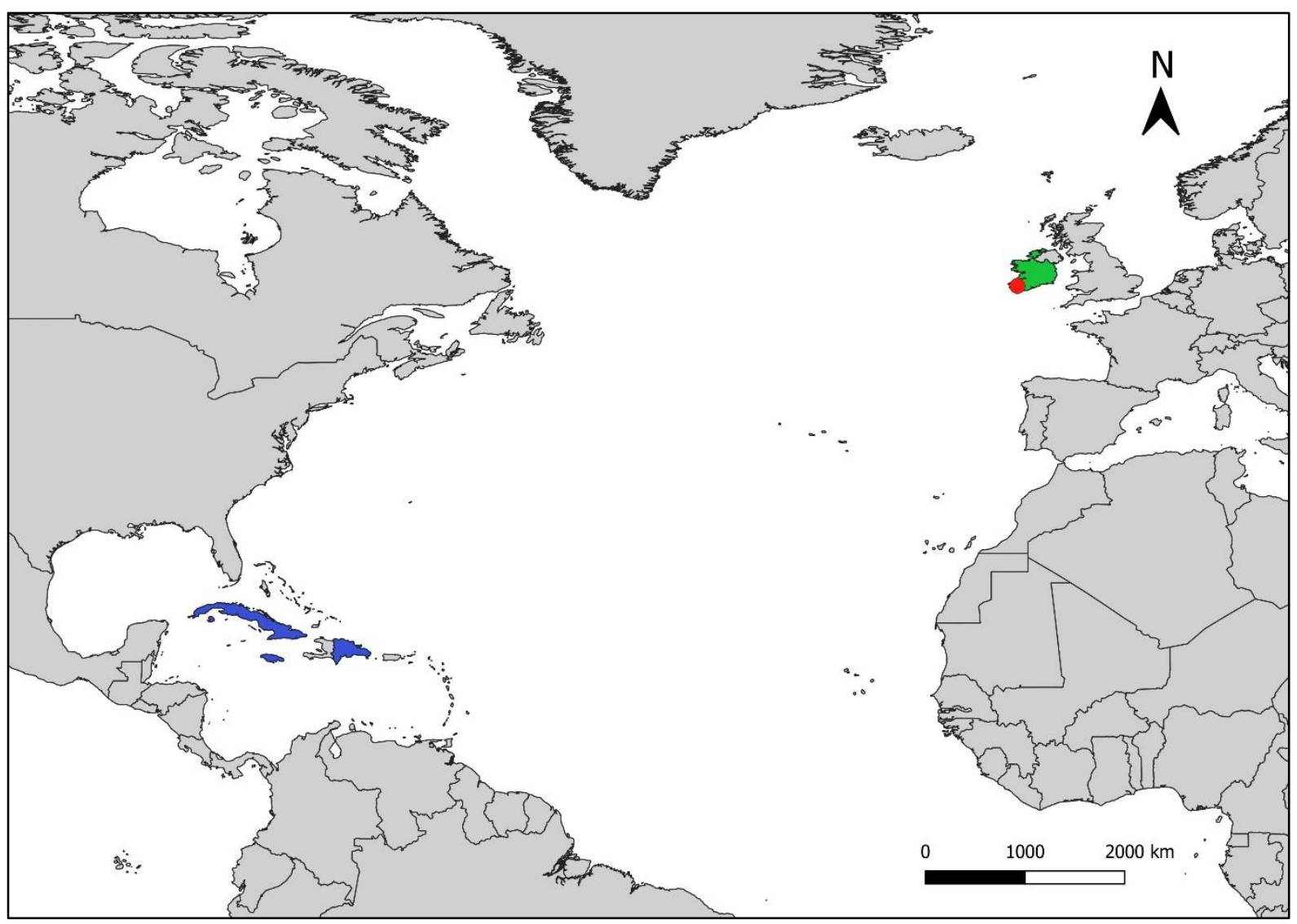

Figure 4: Map of the North Atlantic showing the current known worldwide distribution of Stenogrammitis myosuroides. The countries marked in blue represent its previous known distribution, while the red dot represents the approximate location of the new discovery.

facilitate the carrying of spores between the Caribbean and Ireland. The climate of the site of $S$. myosuroides would be similar in many ways to that of the Neotropical montane cloud forests from which the spores would have originated, with high levels of humidity and little to no frost in most winters, resulting from the flow of tropical air, driving warm currents, from the southwest (Sweeney, 2014). This climatic similarity would greatly aid the establishment and survival of $S$. myosuroides and facilitate its spread in suitable habitat.

If considered native it seems remarkable to think that a species, indeed a distinctive genus, might have been overlooked until now. While the Killarney area has been a mecca for both bryologists and pteridologists since the early $19^{\text {th }}$ century, it has, in truth, not been exhaustively worked away from certain known hotspots, such as the Torc area. While earlier cryptogamists did indeed make finds of rather cryptic taxa eg. Hypnum uncinulatum Jur. that were to be overlooked and evade later investigators for over a century (Ando \& Townsend, 1980; Lockhart et al., 2012), we think it not improbable that a species like the Stenogrammitis (small, unexpected and unfamiliar, with exacting ecology, only ever present as few individuals and possibly even largely persisting, as does the N. American G. nimbata, in gametophyte form), could have remained unobserved. The possibility of the Stenogrammitis'Irish occurrence having resulted from natural dispersal we believe to be credible and indeed the most plausible scenario. As to when such an event may have occurred we cannot currently say, although the small differences we note 
from typical $S$. myosuroides might indicate a long period of isolation. Elucidation of this and indeed the taxonomic status of the Irish population will await molecular investigation.

\section{Acknowledgements}

We thank Paulo Labiak and Michael Sundue for their assistance and interest.

\section{References}

Ando, H. \& Townsend, C.C. 1980. Hypnum uncinulatum Jur. Re-instated as an Irish species. Journal of Bryology 11: 185-189.

Christenhusz, M.J.M., Zhang, X.-C. \& Schneider, H. 2011. A linear sequence of extant families and genera of Lycophytes and ferns. Phytotaxa 19: 7-54.

Farrar, D. R. 1967. Gametophytes of four tropical fern genera reproducing independently of their sporophytes in the southern Appalachians. Science 155: $1266--1267$.

García Criado, M., Väre, H., Nieto, A., Bento Elias, R., Dyer, R., Ivanenko, Y., Ivanova, D., Lansdown, R., Molina, J.A., Rouhan, G., Rumsey, F., Troia, A., Vrba, J. \& Christenhusz, M.J.M. 2017. European Red List of Lycopods and Ferns. Brussels: IUCN.

Hansen, A. 1992. Contributions to the flora of the Azores, Madeira, P. Santo and the Canary Islands. Boletim Museo Municipal Funchal 44: 157-179.

Hill, M.O., Preston, C.D., Bosanquet, S.D.S. \& Roy, D.B. 2007. BRYOATT: attributes of British and Irish mosses, liverworts and hornworts. Huntingdon: Centre for Ecology \& Hydrology.

Hodd, R.L. 2015. Survey of Flora Protection Order Bryophytes in counties Cork and Kerry. Unpublished report to National Parks and Wildlife Service, Department of Arts, Heritage and the Gaeltacht, Dublin, Ireland.

Hodd, R.L. 2020. BBS Summer meeting 2019: Kenmare week, 7-13 July. Field Bryology 123.

Holyoak, D. \& Lockhart, N. 2009. Australasian bryophytes introduced to South Kerry with tree ferns. Field Bryology 98: 3-7.

Labiak, P.H. 2011. Stenogrammitis, a new genus of grammitid ferns segregated from Lellingeria (Polypodiaceae). Brittonia 63: 139-149.

Labiak, P.H. 2012. A New Species and a New Hybrid in the Grammitid Fern Genus Stenogrammitis (Polypodiaceae). American Fern Journal 102: 161-166.

Lockhart, N.D., Hodgetts, N.G. \& Holyoak, D.T. 2012. Rare and Threatened Bryophytes of Ireland. Hollywood: National Museums Northern Ireland.

Maxon, W.R. 1905. On the names of three Jamaican species of Polypodium. Bulletin of the Torrey Botanical Club 32: 73-75.

Pyner, T. 2016. Tmesipteris growing on Dicksonia in an English garden. [Online]. [Accessed 28/04/2020]. Available at: <https://ebps.org.uk/tmesipterisgrowing-dicksonia-english-garden/>.

Ranker, T.A., Smith, A.R., Parris, B.S., Geiger, J.M., Haufler, C.H., Straub, S.C. \& Schneider, H. 2004. Phylogeny and evolution of Grammitid ferns (Grammitidaceae): A case of rampant morphological homoplasy. Taxon 53: 415-428.

Rasbach, H., Rasbach, K. \& Reichstein, T.R. 1974. Grammitis jungermannioides in the Azores. Fern Gazette 11: 49-52. 
Rumsey, F.J., Jermy, A.C. \& Sheffield, E. 1998. The independent gametophyte stage of the Killarney fern Trichomanes speciosum Willd. (Hymenophyllaceae) and its distribution in Britain and Ireland. Watsonia 22: 1-19.

Rumsey, F. J., Raine, C. A . \& Sheffield, E. 1993. Trichomanes venosum R.Br. (Hymenophyllaceae: Pteridophyta) in a Cornish garden - with a key to the filmy-ferns established in Britain and Ireland. Fern Gazette 14: 155-160.

Schäfer, H. 2001. The Grammitidaceae, Pteridophyta, of Macaronesia. Feddes Repertorum 112: 509-523.

Schäfer, H. 2005. Endemic vascular plants of the Azores: an updated list. Hoppea 66: $275-283$.

Schneider, H., Smith, A.R., Cranfill, R., Hildebrand, T., Haufler, C.H., Ranker, T. 2004. Unravelling the phylogeny of polygrammoid ferns (Polypodiaceae and Grammitidaceae): Exploring aspects of the diversification of epiphytic plants. Molecular Phylogenetics and Evolution 31: 1041-1063.

Schuettpelz, E. \& Pryer, K.M. 2007. Fern phylogeny inferred from 400 leptosporangiate species and three plastid genes. Taxon 56: 1037-1050.

Schuettpelz, E. et al., 2016. A Community-derived classification for extant lycophytes and ferns. Journal of Systematics and Evolution 54: 563-603.

Smith, A.R. 1993. Grammitidaceae in Flora of North America: North of Mexico Vol. 2: 390. Oxford: Oxford University Press.

Smith, A.R., Moran, R.C. \& Bishop, L.E. 1991. Lellingeria, a new genus of Grammitidaceae. American Fern Journal 81: 76-88.

Sundue, M.A., Parris, B.S., Ranker, T.A., Smith, A.R., Fujimoto, E.L., Zamora-Crosby, D., Morden, C.W., Chiou, W-L., Chen, C-W., Rouhan, G., Hiral, R.Y. \& Prado, J. 2014. Global phylogeny and biogeography of grammitid ferns (Polypodiaceae). Molecular Phylogenetics and Evolution 81: 195-206.

Sweeney J. 2014. Regional weather and climates of the British Isles - Part 6: Ireland. Weather 69: 20-27.

Copyright retained by author(s). Published by BSBI under the terms of the Creative Commons Attribution 4.0 International Public License.

ISSN: $2632-4970$

https://doi.org/10.33928/bib.2020.02.158 